University of Nebraska - Lincoln

DigitalCommons@University of Nebraska - Lincoln

Nebraska Cooperative Fish \& Wildlife Research Nebraska Cooperative Fish \& Wildlife Research Unit -- Staff Publications

2008

\title{
Lure-size Restrictions in Recreational Fisheries
}

Gene R. Wilde

Texas Tech University, gene.wilde@ttu.edu

Kevin L. Pope

University of Nebraska-Lincoln, kpope2@unl.edu

Bart W. Durham

Wildlife and Fisheries Management Institute

Follow this and additional works at: https://digitalcommons.unl.edu/ncfwrustaff

Part of the Other Environmental Sciences Commons

Wilde, Gene R.; Pope, Kevin L.; and Durham, Bart W., "Lure-size Restrictions in Recreational Fisheries" (2008). Nebraska Cooperative Fish \& Wildlife Research Unit -- Staff Publications. 89.

https://digitalcommons.unl.edu/ncfwrustaff/89

This Article is brought to you for free and open access by the Nebraska Cooperative Fish \& Wildlife Research Unit at DigitalCommons@University of Nebraska - Lincoln. It has been accepted for inclusion in Nebraska Cooperative Fish \& Wildlife Research Unit -- Staff Publications by an authorized administrator of DigitalCommons@University of Nebraska - Lincoln. 


\section{है (1) Lure-size Restrictions in Recreational Fisheries}

We conducted angling experiments to examine the potential use of lure-size restrictions to effect or reinforce length limits. We used four sizes of lures and five color patterns to assess effects of lure size and color on the number and length of largemouth bass (Micropterus salmoides) captured by angling. There was a significant $(F=12.03 ; \mathrm{df}=1,177 ; P=0.0007$ ) lure-size effect on the total length $(T L)$ of captured largemouth bass. Catch rates of fish $\geq 305-\mathrm{mm}$ TL ranged from 0 to 0.5 fish per hour and were unrelated to lure size. Lure color pattern had no effect on length of fish captured $(F=1.44 ; \mathrm{df}=4,230 ; P=0.2320)$. Angling experiments and results from angling simulations suggest lure-size restrictions can be used to indirectly effect or reinforce minimum-length limits and provide managers with a means to reduce catch of nontarget-size fish.

\section{Introduction}

Length and possession (creel or bag) limits are among the most commonly used regulations for management of recreational fisheries. Although several types of length limits (e.g., minimum, maximum, protected slot, and inverse slot) are used to manage fisheries, all require that anglers release certain sizes of fish. Daily possession limits also require release of captured fish after anglers' catches reach prescribed limits. Depending on environmental conditions such as water temperature (Muoneke 1992) and dissolved oxygen concentration (Hickman 1998), angler handling (Cooke et al. 2001), bait type (e.g., live bait versus artificial lures) (Clapp and Clark 1989; Diggles and Ernst 1997), bait orientation (Broadhurst and Hazin 2001), and hook type (Klein 1965; Matlock et al. 1993), a variable proportion of released fish does not survive capture, handling, and release. Mortality rates of released fish often are acceptable but typically are believed to be "high," warranting management attention, when they exceed 20\% (Muoneke and Childress 1994).

The success of length limits in attaining their intended purposes depends on the survival of released fish (Muoneke and Childress 1994). Although mortality of angler caught and released fish can be very low (Dunmall et al. 2001; Diggles and Ernst 1997), it may be excessive at certain times of the year or for fish captured under specific circumstances. For example, Wilde et al. (2000) reported that mortality of striped bass (Morone saxatilis) could exceed 30\% (artificial lures) to $40 \%$ (natural baits) during summer when water temperatures exceed $25^{\circ} \mathrm{C}$. Mortality of red snapper (Lutjanus campechanus) increases with depth of capture, with a mortality rate of $44 \%$ observed among fish captured at 37 to $40 \mathrm{~m}$ (Gitschlag and Renaud 1994). Similarly, mortality of yellow perch (Perca flavescens) (Keniry et al. 1996) and largemouth bass (Micropterus salmoides) (Feathers and Knable 1983 ) is related to depth of capture, and can exceed 50\% among fish captured from depths greater than 15 $\mathrm{m}$ (yellow perch) or $27 \mathrm{~m}$ (largemouth bass). Anglers targeting these species may catch and release a substantial number of fish, which are subject to a high rate of catch-and-release mortality, before catching their limits of legal-length fish. Under these conditions, catch and release is inconsistent with Armstrong et al.'s (1990) concept of good fisheries management, which requires that fishing gears catch target-length fish while allowing nontarget-length individuals to escape unharmed. Further, high rates of mortality are difficult to defend in light of the ongoing debate about the ethical status of catch-and-release fishing (de Leeuw 1996; Balon 2000; Aas et al. 2002).

The size of prey that predatory fishes can capture and consume is directly related to predator length and gape (Werner 1974; Dennerline and Van Den Avyle 2000; Hartman 2000). Because most recreationally important fishes are carnivorous, these relationships between predator length and prey size suggest that, on average, the size of baits or artificial lures used by recreational anglers might be regulated to manipulate length of fish captured (Miranda and Dorr 2000). Catch rates of commercial fishing gears for undersized fish which, must be discarded and which reduce fishing efficiency for larger, more valuable individuals, can be reduced by using larger baits (Løkkeborg 1990; Løkkeborg and Bjordal 1995; Huse and Soldal 2000), hooks (Cortez-Zaragoza et al. 1989; Otway and Craig 1993), and lures (Orsi 1987; Orsi et al. 1993). Further, catch rates of larger fish may be unaffected (e.g., Willis and Millar 2001), or may even increase because of increased gear efficiency (Ralston 1990) and reduced competition between small and large fish (Løkkeborg and Bjordal 1992). In this article we provide an experimental evaluation of the potential use of lure-size restrictions to reduce the catch of undersized fish as a means for indirectly implementing, or reinforcing, a minimum-length limit. We use computer simulations to further explore the relationship between largemouth bass population size structure and lure-size effects on the length of fish caught. Because lure color may affect catch rates (Hsieh et al. 2001) we also present results from an experimental assessment of 


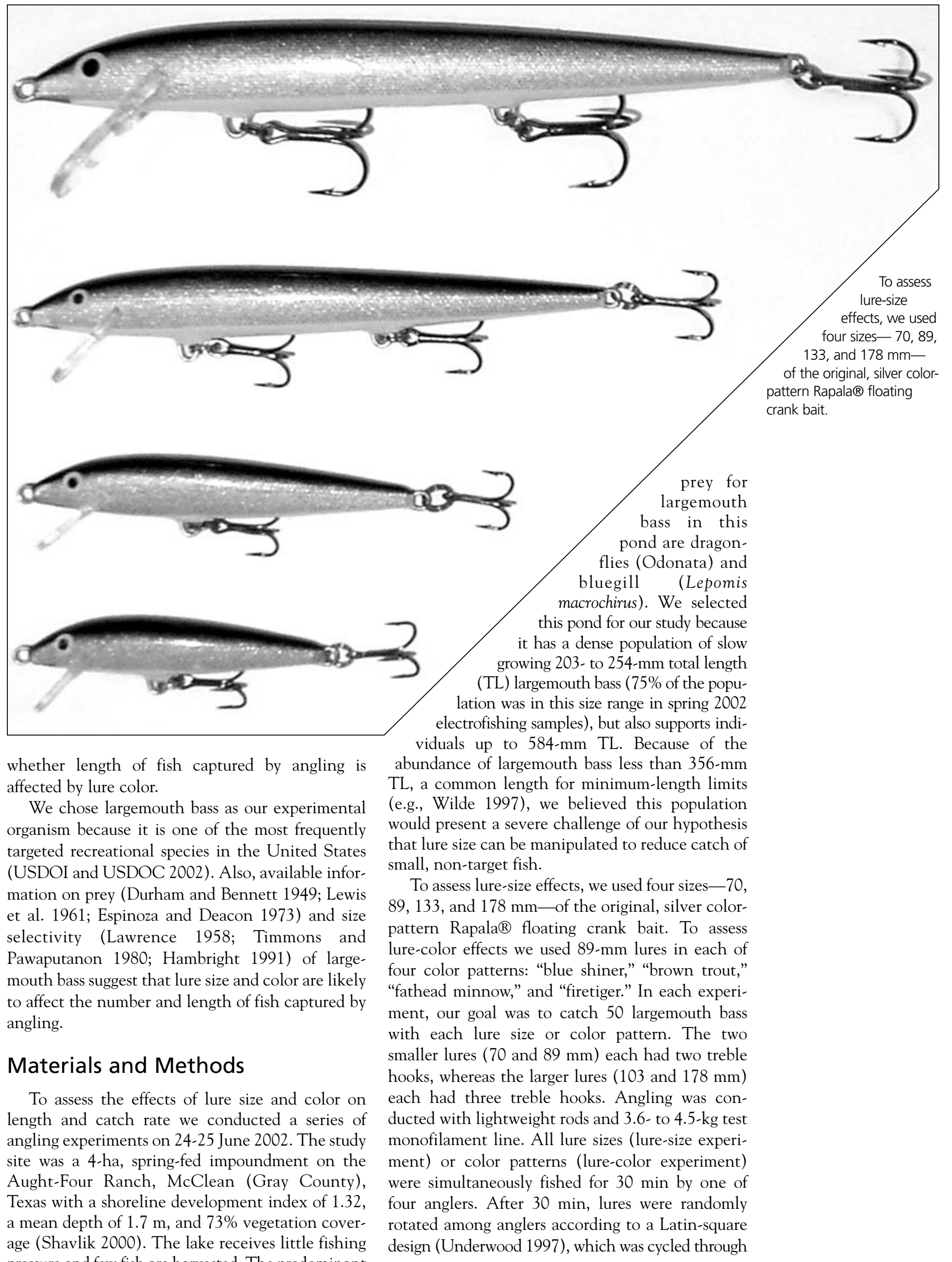
pressure and few fish are harvested. The predominant 


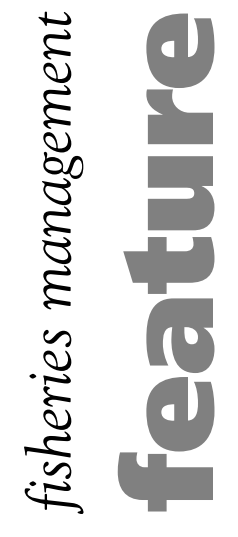

approximately every $2.5 \mathrm{~h}$ allowing $30 \mathrm{~min}$ during each cycle for switching lures and angler breaks. Once at least 50 fish were captured on a given lure size or color pattern, that lure was replaced in the rotation with the size or color of lure on which the smallest number of fish had been caught. Number of fish captured in each fishing period, length of captured fish, and lure size and color were recorded.

We did not mark or tag fish released during our experiments, thus it is possible that some fish were captured more than once. We believe that few fish were recaptured in our experiments because largemouth bass, once captured, generally are not quickly recaptured (Hackney and Linkous 1978).

\section{Analysis of Length Frequencies}

We used S-Plus version 6.0 (Insightful Corp., Seattle, Washington) software to fit a generalized linear model (McCullagh and Nelder 1989) to assess the effects of lure size (length in $\mathrm{mm}$ ) on length of

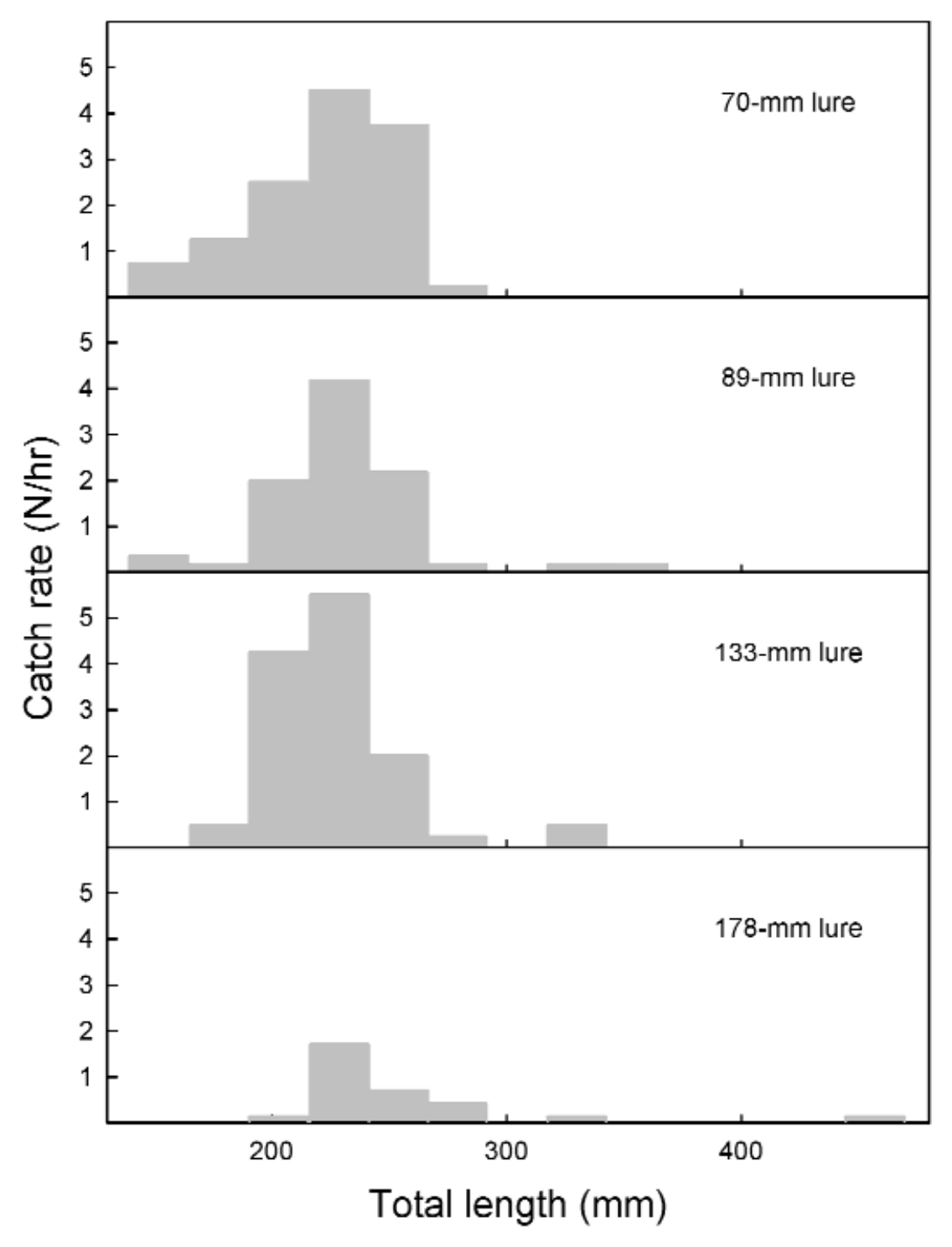

captured largemouth bass. Length frequencies of captured largemouth bass in our study were unimodal and slightly skewed to the right (Figure 1); therefore, we assumed a gamma distribution for our model error distribution and used an identity (non-transformed) link function.

We used a generalized linear model to assess the effects of lure color on length of captured largemouth bass. In addition to the four lure color-patterns used specifically to examine color effects, we also included results for the $89-\mathrm{mm}$ silver-colored lure in this analysis because we did not expect any difference in size selectivity between days. We assumed a gamma distribution for model errors because length frequencies of captured fishes were unimodal and slightly skewed to the right (Figures 1 and 2). We used an identity link function in this model.

\section{Analysis of Catch Rates}

We modeled catch rate (fish per hour) as a Poisson variable and used a generalized linear model with a log link function to assess the effects of lure size on catch rate. We tested the null hypothesis that catch rates for each pair of lures were equal (two-tailed test). We assessed lure-size effects on three sizes of fish (all lengths combined, fish $\geq 254-\mathrm{mm}$ TL, and fish $\geq 305-\mathrm{mm}$ TL). For each size, we controlled the experimentwide error rate with the sequential-Bonferroni adjustment (Rice 1989). For the lure color-pattern experiment, we again modeled catch rate (fish per hour) as a Poisson variable and fit generalized linear models using a log link function for each pair wise combination of lure color-patterns except for the silver color-pattern. The null hypothesis for these tests was that catch rates were equal (two-tailed test) for all color patterns. The experiment-wide error rate was controlled with the sequential-Bonferroni adjustment. We excluded the silver color-pattern from these analyses because fish were captured on a different day and,

Figure 1. Length frequencies of largemouth bass captured on artificial lures (crank baits) that ranged in length from 70 to $178 \mathrm{~mm}$. The 70- and 89-mm lures each had two \#7 treble hooks, whereas the 133- and 178$\mathrm{mm}$ lures each had three treble hooks (\#5 hooks on the 133-mm lure and \#1 hooks on the 178-mm lure). All lure sizes were fished simultaneously and were rotated among anglers every $30 \mathrm{~min}$. Assignment of lures to anglers followed a Latin-square design. 
therefore, differences in catch rates might be attributable either to temporal or color effects.

\section{Angling Simulations}

We used computer simulations to assess the ability of lure-size restrictions to manipulate length of largemouth bass captured from populations differing in size structure. In these simulations we first estimated the size-selectivity of the 70- and 178-mm lures by comparing lengths of fish captured with each lure with those of largemouth bass captured from the AughtFour pond during spring 2002 electrofishing. For both lures, size-selectivities were scaled to range from 0 to 1. We simulated three largemouth bass populations that differed from each other, and that of the AughtFour pond, in size structure. These populations were characterized by a bimodal length frequency (Wynne et al. 1993; Figure 1, data for 1988), a unimodal length frequency in which most fish were 2325-mm TL (Wynne et al. 1993; Figure 1, data for 1992), and a unimodal length frequency in which fish were most abundant between 275- and 350-mm TL (Ebbers 1987; Figure 2, 1983 electrofishing data). We selected at random, with replacement, fish from each population. For each selected fish, a random variate was drawn from a uniform $(0,1)$ distribution. If the random variate was less than or equal to the lure selectivity for that size of fish, the fish was considered as "captured." We performed simulations until 500 fish were captured from each simulated population on each lure. Angling simulations were coded in MATLAB (The MathWorks, Inc.).

\section{Results}

In the lure-size experiments we captured 179 largemouth bass, which ranged from 152 to $457 \mathrm{~mm}$ in TL (Figure 1). Mean lengths ( \pm SE) of largemouth bass captured on the four lures were: $233 \pm 3.8 \mathrm{~mm}$ (70-mm lure); $243 \pm 4.8 \mathrm{~mm}$ (89-mm lure); $240 \pm 4.1 \mathrm{~mm}$ (133-mm lure); and $267 \pm 10.6 \mathrm{~mm}$ (178-mm lure). There was a significant relationship between length of fish captured

Figure 2. Length frequencies of largemouth bass captured on 89-mm artificial lures (crank baits) varying in color pattern. All color patterns were fished simultaneously and were rotated among anglers every $30 \mathrm{~min}$. Assignment of lures to anglers followed a Latin-square design. $(\mathrm{mm}$ TL) and lure size (LureSize, $\mathrm{mm})(\mathrm{TL}=218.0+$ 0.23 LureSize; $F=12.03 ; \mathrm{df}=1,177 ; P=0.0007, r^{2}=$ 0.07 ) indicating that length of captured largemouth bass increased directly with lure size. We noted a relatively high rate of foul hooking on the 133-mm lure during our angling experiments and attribute the smaller mean length of fish captured on this lure, compared to the $89-\mathrm{mm}$ lure, to small fish captured in this manner.

Catch rates for all sizes of largemouth bass ranged from 3.29 (178-mm lure) to 13 fish per hour (70- and 133-mm lures) (Table 1). Mean catch rates for the 70-, 89-, and 133-mm lures were significantly greater than that for the 178-mm lure. Catch rates for fish $\geq 254 \mathrm{~mm}$ ranged from 1.43 (178-mm lure) to 4 fish per hour (70-mm lure) and differed significantly only between the 70- and 178-mm lures. Mean catch rates for fish $\geq 305 \mathrm{~mm}$ ranged from 0 (70-mm lure) to 0.5 fish per hour (133-mm lure) and differed significantly only between the 70-mm and 178-mm lures.

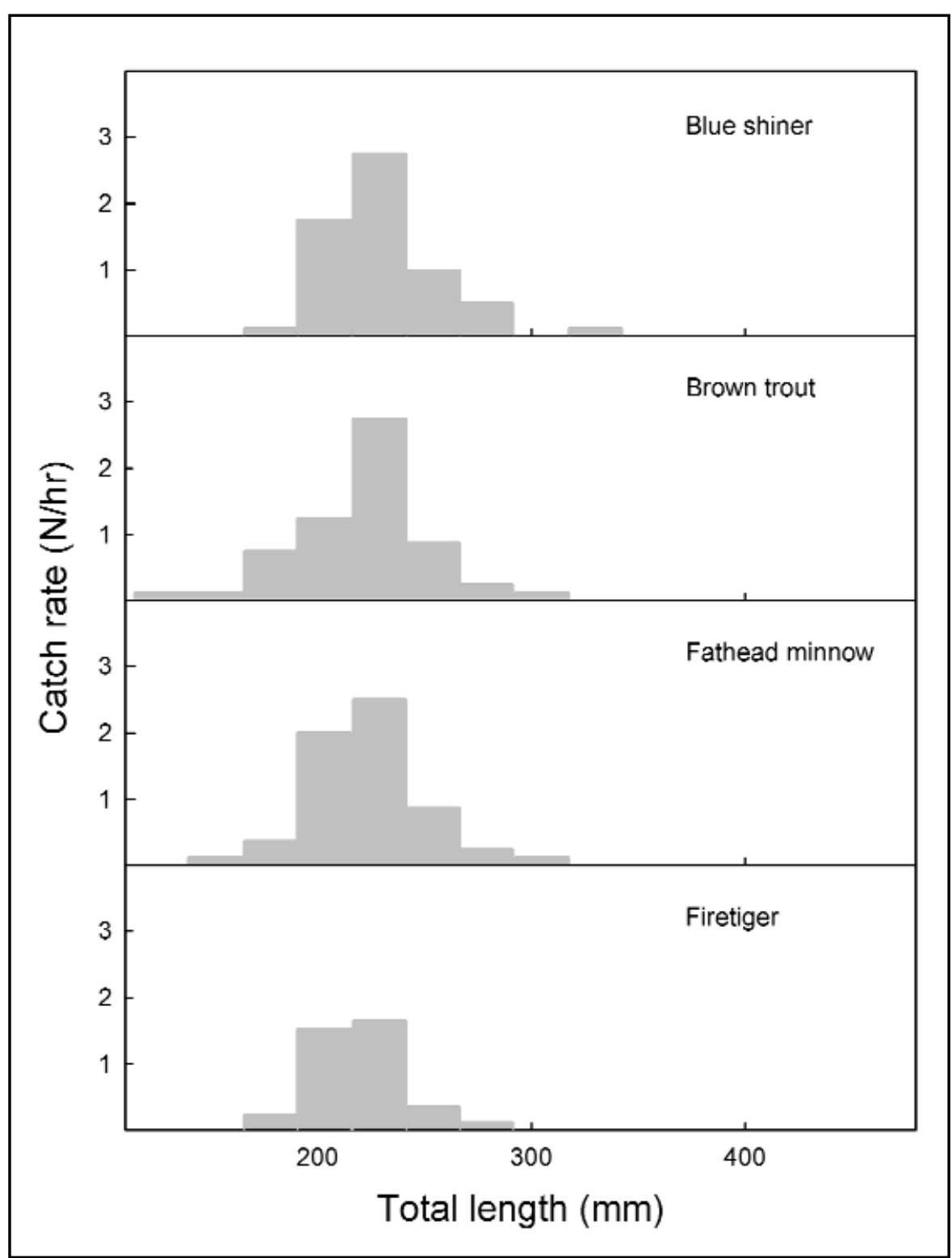




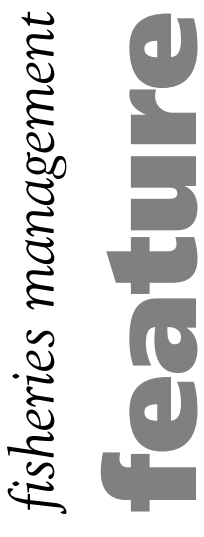

In the lure-color experiments we captured 183 largemouth bass, which ranged in length from 127 to 432-mm TL (Figure 2). We caught an additional 52 largemouth bass, which ranged from 152- to 457-mm TL (Figure 1), on the 89-mm silver colorpattern lure. There was no relationship between length of fish captured and lure color $(F=1.44$; df $=4,230 ; P=0.2320$ ). Largemouth bass catch rates were 3.88 fish per hour with the firetiger pattern, 5.88 per hour with the brown trout pattern, and 6.25 per hour with the blue shiner and fathead minnow color patterns. Catch rates for the firetiger color pattern were significantly $(P<0.05)$ lower than those for the blue shiner and fathead minnow patterns, but there were no apparent differences in catch rates among lure color-pattern combinations.

There was a consistent difference in lengths of fish captured with the small and large lures in each of the simulated populations (Figure 3). In our simulations, mean lengths $\pm \mathrm{SE}$ of fish captured with small lures ranged from $223 \pm 2.9 \mathrm{~mm}$ to $250 \pm 4.1 \mathrm{~mm}$, and mean lengths of those captured with large lures ranged from $323 \pm 2.7 \mathrm{~mm}$ to $353 \pm 3.6 \mathrm{~mm}$. The dif-

Table 1. Mean (+ SE) catch rates (number per hr of angling) of largemouth bass captured using four sizes of artificial lures. Catch rates are calculated separately for all fish captured, those $\geq 254-\mathrm{mm} \mathrm{TL}$, and those $\geq 305-\mathrm{mm}$ TL. The 70 - and $89-\mathrm{mm}$ lures each had two treble hooks, whereas the 133- and 178-mm lures each had three treble hooks. Means within a row followed by the same letter are not significantly different.

\begin{tabular}{|lllll|}
\hline & \multicolumn{4}{c|}{ Lure size $(\mathrm{mm})$} \\
\cline { 2 - 5 } Fish length & 70 & 89 & 133 & 178 \\
\hline All fish & $13.00 \pm 1.27^{\mathrm{y}}$ & $10.40 \pm 1.02^{\mathrm{y}}$ & $13.00 \pm 1.28^{\mathrm{y}}$ & $3.29 \pm 0.48^{\mathrm{z}}$ \\
$\geq 254 \mathrm{~mm}$ & $4.25 \pm 0.73^{\mathrm{y}}$ & $2.80 \pm 0.53^{\mathrm{yz}}$ & $2.75 \pm 0.59^{\mathrm{yz}}$ & $1.43 \pm 0.32^{\mathrm{z}}$ \\
$\geq 305 \mathrm{~mm}$ & $0.00 \pm 0.00^{\mathrm{y}}$ & $0.40 \pm 0.20^{\mathrm{yz}}$ & $0.50 \pm 0.25^{\mathrm{z}}$ & $0.43 \pm 0.18^{\mathrm{y}}$ \\
\end{tabular}

ference in mean length between fish captured on small and large lures was 100,87 , and $111 \mathrm{~mm}$, respectively, in the three simulated populations. Based on simulated catches of 500 individuals, restricting the use of the small lure would result in a $28 \%$ to $46 \%$ reduction in the catch of undersized fish under a $356-\mathrm{mm}$ minimum length limit and a $14 \%$ to $36 \%$ reduction under a $381-\mathrm{mm}$ minimum length limit. The simulated population dominated by fish $\geq 325$-mm TL (Figure 3b) showed the greatest reduction in catch of undersized fish.

\section{Discussion}

Our results demonstrate that the number and length of fish captured by anglers can be manipulated by regulating lure size. In our angling experiment we observed a $33-\mathrm{mm}$ increase in mean length between largemouth bass caught with the 70 and $178-\mathrm{mm}$ lures. This difference represents $11 \%$ of the observed range in length of largemouth bass (152 - to 457-mm TL) in this population, which is dominated by individuals that are 254- to $305-\mathrm{mm}$ TL. We believe that a greater difference in mean length among fish captured with different sizes of lure would be observed in populations with a more balanced size structure (Erzini et al. 1996, 1997). Indeed, this is supported by our angling simulations, which showed that mean lengths of fish captured on small and large lures differed by 87 to $111 \mathrm{~mm}$ depending on population size structure.

Our simulations show that catches of fish smaller than $356-\mathrm{mm}$ and $381-\mathrm{mm}$ TL can be reduced by $28 \%$ to $47 \%$ and $14 \%$ to $36 \%$, respectively, if anglers were restricted from using the 70-mm lure and instead used the 178-mm lure. These results are based on catches of 500 individuals on each lure and do not consider differences among lures in catch rate. Largemouth bass catch rates on the large lure were approximately one-third those of the small lure in our angling experiments. If the number of fish captured with the large lure in our simulations is reduced by $66 \%$, use of the large lure alone could reduce the catch of fish smaller than 356-mm and 381-mm TL by $76 \%$ to $82 \%$ and $72 \%$ to $79 \%$, respectively.

Largemouth bass catch rates during our angling experiments ranged from 10 to 13 fish per hour on the 70-, 89-, and 133-mm lures, but were only 3.29 per hour on the 178-mm lure. Because there was little difference among lures in catch rates of fish $>305-\mathrm{mm}$ TL ( 0 to 0.5 fish per hour), differences in catch rates among lures are due to their relative efficiency in capturing fish $<305-\mathrm{mm} \mathrm{TL}$, which generally are protected by minimum-length limits. Notably, the smallest lure used in our experiments caught no fish larger than 279-mm TL. This may be a result of sampling variation or competition between the abundant small fish and the less abundant, larger fish (Løkkeborg and Bjordal 1992).

We anticipated a possible lure color-pattern effect on largemouth bass catch rates based on the results of Brown (1937), Durham and Bennett (1949), and Hsieh et al. (2001), but had no preconceptions about potential effects on length of captured fish. Lure colorpattern affected catch rates, but had no effect on length of largemouth bass captured in our experiments. We conclude there is no need to consider lure color when implementing a lure-size restriction.

We believe that lure-size restrictions could be used to emulate or reinforce slot- or maximum-length limits, as well as minimum-length limits, in some species. Mouth shape and width affect prey-size selectivity (Huskey and Turingan 2001; Magnhagen and Heibo 2001) and determine which types of length limits might be effected (Cortez-Zaragoza et al. 1989). For example, as a fish grows progressively larger prey is included in the diet, but smaller prey generally is not excluded (Juanes 1994). This pattern of prey utilization should result in a logistic, or s-shaped, size-selectivity curve (Kenchington 1993) in fishes that have a large gape such as largemouth bass and barramundi (Lates calcarifer). Because only smaller 
individuals are prey-size limited, a logistic selectivity curve would suggest that a minimum-length limit could be effected or reinforced with lure-size restrictions. In contrast, fishes with a small gape, such as bluegill and roach (Rutilus rutilus), would be more likely to exhibit non-monotonic size-selectivity curves that can be modeled as normal, skew-normal, and gamma distributions (Kenchington 1993). Such selectivity curves suggest, for a fish of given length, there is an optimum prey size (Werner 1974, 1979) and that progressively smaller or larger prey are increasingly less likely to be attacked. In these species, it may be possible to effect or reinforce minimum-length limits by restricting the use of small lures, maximum-length limits by restricting the use of large lures, and slot-length limits by restricting the use of smaller and larger lures. The effectiveness of these restrictions would likely be related to the width of the prey-size selectivity curve for a given species.

Numerous precedents for bait and lure restrictions exist in recreational fisheries. Anglers in some areas are required to use artificial baits (lures and flies) or flies only, with further restrictions on hook number, size, configuration (single versus treble), and presence of barbs (e.g., Seehorn 1984). These restrictions generally are used to manage specialty fisheries in relatively small, localized areas. We envision management of such fisheries as one potential use for lure-size restrictions. A second use might be on small, private impoundments where catches of undersized fish are problematic and gear restrictions can be easily implemented. Perhaps the most important, but controversial, use of lure-size restrictions would be on larger water bodies, where there is a need to reduce the catch of certain sizes of fish. On these waters, lure- (and bait-) size restrictions could be coupled with length limits to reduce catches of undersized (or nontarget-length) individuals. We anticipate some initial opposition to the use of luresize restrictions because anglers generally indicate less support for gear and bait restrictions than for length limits (Wilde and Ditton 1991) and because catch is an important determinant of fishing satisfaction (Holland and Ditton 1992; Spencer 1993; Finn and Loomis 2001). However, it is impossible to accurately predict angler response to a lure-size restriction because anglers differ in the importance they attach to catching fish of different sizes (Hudgins 1984): some anglers prefer to catch a greater number of smaller fish, whereas others prefer to catch a smaller number of large fish (Wilde and Ditton 1994; Fisher 1997). Differences in anglers' preferences for different sizes of
Figure 3. Length frequencies of simulated largemouth bass populations (gray histograms) and of fish captured in angling simulations using 70- (black bars) and 178-mm lures (gray bars). Size-structure information for simulated populations was obtained from Wynne et al. (1993) for panels $A$ and $B$ and Ebbers (1987) for panel C. 


\section{1}

Kevin Pope and Felix

Martinez, Jr. at the AughtFour pond with a largemouth bass captured on the 178-mm lure. fish will likely be reflected in their responses to a luresize restriction. Our observation that catch rates of larger fish are unaffected by lure-size restrictions may assuage angler concerns. Lure-size restrictions have the potential to simultaneously increase angler effectiveness and conserve fishery resources by reducing catch and mortality of nontarget-length fish. We believe this message would be of interest to many conservationoriented anglers.

Recreational angling is highly selective and arguably has a greater effect on fish population dynamics than does any other factor in inland waters. However, in contrast to commercial fisheries (e.g., Ralston 1990; Løkkeborg and Bjordal 1992; Erzini et al. 1996), surprisingly little is known about the gear used in recreational fisheries. Such information would be useful in implementing gear, including lure-size, restrictions (Broadhurst et al. 1999). For example, there is as yet no consensus on something as basic as whether barbless hooks reduce mortality of captured and released fish (Taylor and White 1992; Schill and Scarpella 1997). Angling methods and gear used by recreational anglers are selective toward larger fishes (Gabelhouse and Willis 1986; Pierce and Cook 2000). The size of terminal gear (tackle) may affect both length and number of fish captured (Orsi 1987; Miranda and Dorr 2000; this study). In this article we suggest only one way that information on gear selectivity might be useful in fishery management, but this information also will be useful in developing and refining various models of the angling process (e.g., Raat 1985; Deriso and Parma 1987; Shimizu et al. 1996) to provide a better understanding of gear selectivity and fishery impacts of recreational angling. Because the length and species of fish available, hence vulnerable, to recreational anglers varies by season and location
(Gabelhouse and Willis 1986; Pope and Willis 1996; Schultz and Schneider 1999), a few thorough studies documenting seasonality and frequency of use of various terminal gears by anglers would be valuable.

Catch-and-release mortality remains problematic in many instances. Black bass (Micropterus spp.) captured and released in fishing tournaments during the 1970s suffered a high rate of mortality, which resulted in public outcry and adoption and refinement of liverelease practices by tournament sponsors and participants (Holbrook 1975; Wilde et al. 2002). Although mortality since has been reduced to about 27\% (Wilde 1998), it still exceeds the 20\% criterion of Muoneke and Childress (1994). Similarly, despite extensive study (e.g., Muoneke and Childress 1994; Lucy and Studholme 2002) mortality of fish captured and released by recreational anglers remains high in certain situations, such as when fishes are captured from depth (Gitschlag and Renaud 1994; Keniry et al. 1996) or during the warm season (Wilde et al. 2000). To date, high mortality of released fish in these circumstances has not been adequately addressed, although some initial attempts have been made. For example, a 356-mm minimum-length limit for walleye (Stizostedion vitreum) is in force from April through June on Lake Francis Case, South Dakota. The length limit is suspended during the rest of the year to allow retention of undersized walleye during summer when they are captured in warm water, and in winter when they are typically captured from deep water (Stone and Lott 2002). In Texas, a 254-mm minimum-length limit for crappie (Pomoxis spp.) is suspended on some reservoirs during winter, with the requirement that anglers retain all captured crappie, because of unacceptably high mortality attributed to capture from deep water. Seasonal suspension of length limits provides one means for reducing high catch-and-release mortality; however, it calls into question the ability of the regulation to effect changes in fishery characteristics such as size structure and catch rate. Modeling studies demonstrate that projected benefits of length limits are compromised by relatively modest rates of mortality of protected-length fish (Waters and Huntsman 1986). Consequently, alternative approaches to reducing mortality of released fishes should be explored. Lure- (and bait-) size restrictions, 


\section{References}

Aas, Ф., C. E. Thaling, and R. B. Ditton. 2002. Controversy over catchand-release fishing in Europe. Pages 95-106 in T. J. Pitcher and C. Hollingworth, eds. Recreational fisheries: ecological, economic, and social evaluation. Blackwell Science, Oxford, UK.

Armstrong, D. W., R. S. T. Ferro, D. N. MacLennan, and S. A. Reeve. 1990. Gear selectivity and the conservation of fish. Journal of Fish Biology 37A:261-262.

Balon, E. K. 2000. Defending fishes against recreational fishing: an old problem solved in the new millennium. Environmental Biology of Fishes 57:1-8.

Broadhurst, M. K., D. T. Barker, and S. J. Kennelly. 1999. Scale loss and survival of juvenile yellowfin bream, Acanthopagrus australis, after simulated escape from a Nordmøre-grid guiding panel and release from capture by hook and line. Bulletin of Marine Science 64:255268.

Broadhurst, M. K., and F. H. V. Hazin. 2001. Influences of type and orientation of bait on catches of swordfish (Xiphias gladius) and other species in an artisanal sub-surface longline fishery off northeastern Brazil. Fisheries Research 53:169-179.

Brown, F. A., Jr. 1937. Responses of the large-mouth black bass to colors. Illinois Natural History Survey Bulletin 21:33-33.

Clapp, D. F., and R. D. Clark. 1989. Hooking mortality of smallmouth bass caught on live minnows and artificial spinners. North American Journal of Fisheries Management 9:81-85.

Cooke, S. J., D. P. Phillip, K. M. Dunmall, and J. F. Schreer. 2001. The influence of terminal tackle on injury, handling time, and cardiac disturbance of rock bass. North American Journal of Fisheries Management 21:333-342.

Cortez-Zaragoza, E. P. Dalzell, and P. Pauly. 1989. Hook selectivity of yellowfin tuna (Thunnus albacares) caught off Darigayos Cove, La Union, Philippines. Journal of Applied Ichthyology 5:12-17.

de Leeuw, A. D. 1996. Contemplating the interests of fish: the angler's challenge. Environmental Ethics 18:373-390.

Dennerline, D. E., and M. J. Van Den Avyle. 2000. Sizes of prey consumed by two pelagic predators in US reservoirs: implications for quantifying biomass of available prey. Fisheries Research 4:147-154.

Deriso, R. B., and A. M. Parma. 1987. On the odds of catching fish with angling gear. Transactions of the American Fisheries Society 116:244256.

Diggles, B. K., and I. Ernst. 1997. Hooking mortality of two species of shallow-water reef fish captured by recreational angling methods. Marine and Freshwater Research 48:479-483.

Dunmall, K. M., S. J. Cooke, F. J. Schreer, and R. S. McKinley. 2001. The effect of scented lures on hooking injury and mortality of smallmouth bass caught by novice and experienced anglers. North American Journal of Fisheries Management 21:242-248.

Durham, L., and G. W. Bennett. 1949. Bass baits at Ridge Lake. Illinois Wildlife 4(2):10-13.

Ebbers, M. A. 1987. Vital statistics of a largemouth bass population in Minnesota from electrofishing and angler-supplied data. North American Journal of Fisheries Management 7:252-259.

Erzini, K., J. M. S. Gonçalves, L. Bentes, and P. G. Lino. 1997. Fish mouth dimensions and size selectivity in a Portuguese longline fishery. Zeitschrift für angewandte Ichthyologie 13:41-44.

Erzini, K., J. M. S. Gonçalves, L. Bentes, P. G. Lino, and J. Cruz. 1996. Species and size selectivity in a Portuguese multispecies artisanal longline fishery. ICES Journal of Marine Science 53:811-819.

Espinoza, F. A., Jr., and J. E. Deacon. 1973. The preference of largemouth bass (Micropterus salmoides Lacépède) for selected bait species under experimental conditions. Transactions of the American Fisheries Society 102:355-362.
Feathers, M. G., and A. E. Knable. 1983. Effects of depressurization upon largemouth bass. North American Journal of Fisheries Management 3:86-90.

Finn, K. L., and D. K. Loomis. 2001. The importance of catch motives to recreational anglers: the effects of catch satiation and deprivation. Human Dimensions of Wildlife 6:173-187.

Fisher, M. R. 1997. Segmentation of the angler population by catch preference, participation, and experience: a management-oriented application of recreation specialization. North American Journal of Fisheries Management 17:1-10.

Gabelhouse, D. W., Jr., and D. W. Willis. 1986. Biases and utility of angler catch data for assessing size structure and density of largemouth bass. North American Journal of Fisheries Management 6:481-489.

Gitschlag, G. R., and M. L. Renaud. 1994. Field experiments on survival rates of caged and released red snapper. North American Journal of Fisheries Management 14:131-136.

Hackney, P. A., and T. E. Linkous. 1978. Striking behavior of the largemouth bass and use of the binomial distribution for its analysis. Transactions of the American Fisheries Society 107:682-688

Hambright, K. D. 1991. Experimental analysis of prey selection by largemouth bass: role of predator mouth width and prey body depth. Transactions of the American Fisheries Society 120:500-508.

Hartman, K. J. 2000. The influence of size on striped bass foraging. Marine Ecology Progress Series 194:263-268.

Hickman, D. S. 1998. Hematology and stress responses of largemouth bass to hypoxia in the Atchafalaya Basin, Louisiana. Master's thesis. Louisiana State University, Baton Rouge.

Holbrook, J. A., II. 1975. Bass fishing tournaments. Pages 408-415 in H. Clepper, ed. Black bass biology and management. Sport Fishing Institute, Washington, D.C.

Holland, S. M., and R. B. Ditton. 1992. Fishing trip satisfaction: a typology of anglers. North American Journal of Fisheries Management 12:28-33.

Hsieh, Y., B. Huang, R. Wu, and C. Chen. 2001. Color effects of lures on the hooking rates of mackerel longline fishing. Fisheries Science 67:408-414.

Hudgins, M. D. 1984. Structure of the angling experience. Transactions of the American Fisheries Society 113:750-759.

Huse, I., and A. V. Soldal. 2000. An attempt to improve size selection in pelagic longline fisheries for haddock. Fisheries Research 48:43-54.

Huskey, S. H., and R. G. Turingan. 2001. Variation in prey-resource utilization and oral jaw gape between two populations of largemouth bass, Micropterus salmoides. Environmental Biology of Fishes 61:185194.

Juanes, F. 1994. What determines prey size selectivity in piscivorous fishes? Pages 79-100 in D. J. Strouder, K. L. Fresh, and R. J. Feller, eds. Theory and application in fish feeding ecology. University of South Carolina Press, Columbia.

Kenchington, T. J. 1993. Estimation of the functional form of selectivity by baited hooks: a graphical approach. Canadian Journal of Fisheries and Aquatic Sciences 50:772-780.

Keniry, M. J., W. A. Brofka, W. H. Horns, and J. E. Marsden. 1996. Effects of decompression and puncturing the gas bladder on survival of tagged yellow perch. North American Journal of Fisheries Management 16:201-206.

Klein, W. D. 1965. Mortality of rainbow trout caught on single and treble hooks and released. The Progressive Fish-Culturist 27:171-172.

Lawrence, J. M. 1958. Estimated sizes of various forage fishes largemouth bass can swallow. Proceedings of the Annual Conference of the Southeastern Association of Game and Fish Commissioners 11:220225.

Lewis, W. M., G. E. Gunning, E. Lyles, and W. L. Bridges. 1961. Food choice of largemouth bass as a function of availability and 
vulnerability of food items. Transactions of the American Fisheries Society 90:355-362.

L $\phi$ kkeborg, S. 1990. Reduced catch of under-sized cod (Gadus morhua) in longlining by using artificial baits. Canadian Journal of Fisheries and Aquatic Science 47:1112-1115.

L $\phi$ kkeborg, S., and Å. Bjordal. 1992. Species and size selectivity in longline fishing: a review. Fisheries Research 13:311-322.

1995. Size-selective effects of increasing bait size by using an inedible body on longline hooks. Fisheries Research 24:273-279.

Lucy, J. A., and A. L. Studholme, editors. 2002. Catch and release in marine recreational fisheries. American Fisheries Society Symposium 30. Bethesda, Maryland.

Magnhagen, C., and E. Heibo. 2001. Gape size allometry in pike reflects variation between lakes in prey availability and relative body depth. Functional Ecology 15:754-762.

Matlock, G. C., L. W. McEachron, J. A. Dailey, P. A. Unger, and P. Chai. 1993. Short-term hooking mortalities of red drums and spotted seatrout caught on single-barb and treble hooks. North American Journal of Fisheries Management 13:186-189.

McCullagh, P., and J. A Nelder. 1989. Generalized linear models, 2nd edition. Chapman and Hall, London.

Miranda, L. E., and B. S. Dorr. 2000. Size selectivity of crappie angling. North American Journal of Fisheries Management 20:706-710.

Muoneke, M. I. 1992. Seasonal hooking mortality of bluegills caught on natural baits. North American Journal of Fisheries Management 12:645-649.

Muoneke, M. I., and W. M. Childress. 1994. Hooking mortality: a review for recreational fisheries. Reviews in Fisheries Science 2:123. 156.

Orsi, J. A. 1987. Small versus large trolling lures for sampling juvenile chinook salmon and coho salmon. Transactions of the American Fisheries Society 116:50-53.

Orsi, J. A., A. C. Wertheimer, and H. W. Jaenicke. 1993. Influence of selected hook and lure types on catch, size, and mortality of trollcaught chinook salmon. North American Journal of Fisheries Management 13:709-722.

Otway, N. M., and J. R. Craig. 1993. Effects of hook size on the catches of undersized snapper, Pagrus auratus. Marine Ecology Progress Series 93:9-15.

Pierce, R. B., and M. F. Cook. 2000. Recreational darkhouse spearing for northern pike in Minnesota: historical changes in effort and harvest and comparisons with angling. North American Journal of Fisheries Management 20:239-244.

Pope, K. L., and D. W. Willis. 1996. Seasonal influences on freshwater fisheries sampling data. Reviews in Fisheries Science 4:57-73.

Raat, A. J. P. 1985. Analysis of angling vulnerability of common carp, Cyprinus carpio L., in catch-and-release angling in ponds. Aquaculture and Fisheries Management 16:171-187.

Ralston, S. 1990. Size selection of snappers (Lutjanidae) by hook and line gear. Canadian Journal of Fisheries and Aquatic Science 47:696-700.

Rice, W. R. 1989. Analyzing tables of statistical tests. Evolution 43: 223225.

Schill, D. J., and R. L. Scarpella. 1997. Barbed hook restrictions in catch-and-release trout fisheries: a social issue. North American Journal of Fisheries Management 17:873-881.

Schultz, R. D., and G. L. Schneider. 1999. Consequences of an exceptional ice-fishing season on white bass in Cheney and Glen Elder Reservoirs, Kansas. Transactions of the Kansas Academy of Science 102:107-116.

Seehorn, M. E. 1984. Special fishing regulations- southeastern style. Pages 115-121, in F. Richardson and R. H. Hamre, eds. Wild trout III. Federation of Fly Fishers, Trout Unlimited, Fish and Wildlife Service, U.S. Department of the Interior, U.S. Department of Agriculture. Yellowstone National Park, Mammoth Springs, WY.
Shavlik, C. E. 2000. An assessment of largemouth bass and panfish population dynamics in west Texas ponds. Master's thesis. Texas Tech University, Lubbock.

Shimizu, S., T. Miura, and K. Nashimoto. 1996. Stochastic model on the hooking mechanism of pole-and-line fishing. Fisheries Science 62:566-572.

Spencer, P. D. 1993. Factors influencing satisfaction of anglers on Lake Miltona, Minnesota. North American Journal of Fisheries Management 13:201-209.

Stone, C., and J. Lott. 2002. Use of a minimum length limit to manage walleyes in Lake Francis Case, South Dakota. North American Journal of Fisheries Management 22:975-984.

Taylor, M. J., and K. R. White. 1992. A meta-analysis of hooking mortality of nonanadromous trout. North American Journal of Fisheries Management 12:760-767.

Timmons, T. J., and O. Pawaputanon. 1980. Relative size relationship in prey selection by largemouth bass in West Point Lake, AlabamaGeorgia. Proceedings of the Annual Conference of the Southeastern Association of Fish and Wildlife Agencies 34:248-252.

Underwood, A. J. 1997. Experiments in ecology. Cambridge University Press, Cambridge.

USDOI and USDOC (U.S. Department of the Interior, Fish and Wildlife Service and U.S. Department of Commerce, Bureau of the Census). 2002. 2001 national survey of fishing, hunting, and wildlifeassociated recreation. U.S. Government Printing Office, Washington, D.C.

Waters, J. R., and G. R. Huntsman. 1986. Incorporating mortality from catch and release into yield-per-recruit analyses of minimum size limits. North American Journal of Fisheries Management 6:463-471.

Werner, E. E. 1974. The fish size, prey size, handling time relation in several sunfishes and some implications. Journal of the Fisheries Research Board of Canada 31:1531-1536.

1979. Niche partitioning by food size in fish communities. Pages 311-322 in H. Clepper, ed. Predator-prey systems in fisheries management. Sport Fishing Institute, Washington, D.C.

Wilde, G. R. 1997. Largemouth bass fishery responses to length limits. Fisheries 22(6):14-23.

1998. Tournament-associated mortality in black bass. Fisheries 23(10):12-22.

Wilde, G. R., and R. B. Ditton. 1991. Diversity among anglers in support for fishery management tools. Pages 329-335 in J. L. Cooper and R. H. Hamre, eds. Warmwater fisheries symposium I. Rocky Mountain Forest and Range Experiment Station, General Technical Report RM-207.

1994. A management-oriented approach to understanding diversity among largemouth bass anglers. North American Journal of Fisheries Management 14:34-40.

Wilde, G. R., M. I. Muoneke, P. W. Bettoli, K. L. Nelson, and B. T. Hysmith. 2000. Striped bass hooking mortality in freshwater. North American Journal of Fisheries Management 20:809-814.

Wilde, G. R., C. E. Shavlik, and K. L. Pope. 2002. Initial mortality of black bass in B.A.S.S. fishing tournaments. North American Journal of Fisheries Management 22:950-954.

Willis, T. J., and R. B. Millar. 2001. Modified hooks reduce incidental mortality of snapper (Pagrus auratus: Sparidae) in the New Zealand commercial longline fishery. ICES Journal of Marine Science 58:830. 841.

Wynne, M. B., A. E. Little, and K. L. Nelson. 1993. Evaluation of a protected slot regulation for largemouth bass on Lake Sutton, North Carolina. Proceedings of the Annual Conference Southeastern Association of Fish and Wildlife Agencies 47:686-694. 